\title{
Growth and grazing on the 'Texas brown tide' alga Aureoumbra lagunensis by the tintinnid Amphorides quadrilineata
}

\author{
Hans Henrik Jakobsen ${ }^{1,2, *}$, Cammie Hyatt ${ }^{3}$, Edward J. Buskey ${ }^{3}$ \\ ${ }^{1}$ Danish Institute for Fisheries Research, Dept of Marine and Coastal Ecology, Kavalergården 6, 2920 Charlottenlund, Denmark \\ ${ }^{2}$ Marine Biological Laboratory, Strandpromenaden 5, 3000 Helsingør, Denmark \\ ${ }^{3}$ Marine Science Institute, University of Texas at Austin, 750 Channel View Drive, Port Aransas, Texas 78373, USA
}

\begin{abstract}
Growth and ingestion by the loricate ciliate Amphorides quadrilineata exposed to increasing dietary doses of the Texas brown tide alga Aureoumbra lagunensis were investigated. The ciliate grew at a maximum rate of $0.38 \mathrm{~d}^{-1}$, ingesting $0.032 \mathrm{ppm}\left(\sim 6.4 \times 10^{2}\right.$ cells $)$ prey $\mathrm{d}^{-1}$ on a diet consisting only of Isochrysis galbana. When A. quadrilineata was offered a mixed diet of $I$. galbana and A. lagunensis, the growth rate decreased when A. lagunensis made up more than ca $40 \%$ of the diet. Ingestion rate by $A$. quadrilineata remained constant with increasing $A$. lagunensis proportion in the diet, which indicates that $A$. quadrilineata did not avoid feeding on $A$. lagunensis. The behaviour of A. quadrilineata was largely unchanged when ciliates were fed A. lagunensis. However A. quadrilineata did perform a significant transient response approx. $60 \mathrm{~min}$ after A. quadrilineata was exposed to A. lagunensis by increasing the turning rate per unit time. This study suggests that efficient top-down control of $A$. lagunensis by heterotrophic protozoans such as the studied ciliate may not happen as long as phytoplankton organisms other than A. lagunensis make up a minor part of the standing phytoplankton stock.
\end{abstract}

KEY WORDS: Texas brown tide $\cdot$ Tintinnid $\cdot$ Growth $\cdot$ Ingestion $\cdot$ Harmful algae $\cdot$ Ciliate $\cdot$ Prey selection

\section{INTRODUCTION}

In the Laguna Madre, Texas, USA, an almost monospecific bloom of the alga Aureoumbra lagunensis Stockwell, DeYoe, Hargraves, et Johnson 1997 existed without interruption from 1990 to 1997, and has reappeared intermittently since then. Compared to most other algal blooms, this bloom is remarkable in its duration. Before the onset of the A. lagunensis bloom, the planktonic food web in Laguna Madre was characterised by heterotrophic dinoflagellates and ciliates of various genera including tintinnid ciliates (Buskey 1993, Buskey \& Stockwell 1993). After the onset of the bloom, the concentration and species diversity of heterotrophic protists was dramatically reduced, indi-

*E-mail: hhj@dfu.min.dk cating that few, if any, protists were able to prey upon and control the stock of $A$. lagunensis (Buskey \& Stockwell 1993). There may be several reasons for the absence of predatory control on A. lagunensis by heterotrophic protozoans. Buskey \& Hyatt (1995) conducted a series of growth experiments with heterotrophic protists feeding on A. lagunensis. They found that growth typically decreased with increasing concentration of A. lagunensis, suggesting that the alga was toxic to some grazers or had a low nutritional value for others. A mucus layer consisting of polysaccharides covers A. lagunensis (EPS: exopolomeric secretion). The amount of EPS around A. lagunensis is dependent on the age of the cells (Villareal et al. 1998) and ambient salinity (Liu \& Buskey 2000a). In another study, Liu \& Buskey (2000b) demonstrated that the effect of $A$. lagunensis on heterotrophic protist grazers was dependent on the amount of EPS per A. lagunensis cell. 
Liu \& Buskey (2000b) hypothesised that EPS may interfere with the feeding organelles of grazers, due to the stickiness of the mucus cover.

In this study we used a ciliate that was growing well when feeding on prey particles of a similar size to Aureoumbra lagunensis. We used a loricate ciliate because there is growing evidence on the importance of tintinnids relative to other oligotrich ciliates in controlling coastal waters with high chlorophyll levels (reviewed by Suzuki \& Taniguchi 1998). The loricate tintinnid ciliate Amphorides quadrilineata Clapréde \& Lachmann 1858 fulfilled these requirements and it was used to study the effects of increasing dietary proportion of A. lagunensis on growth, feeding, prey selection and behaviour of a microzooplankton grazer. We offered A. quadrilineata a mixed diet of A. lagunensis and Isochrysis galbana at a constant biomass in food concentrations markedly lower than those used in the previous study of Buskey \& Hyatt (1995). We also investigated the behaviour of $A$. quadrilineata exposed to $A$. lagunensis to see if the ciliate performed any transient or permanent changes in behaviour in order to avoid ingestion of $A$. lagunensis cells.

\section{MATERIALS AND METHODS}

Isolation and cultivation of the tintinnid. Amphorides quadrilineata was isolated in April 1999 from $20 \mu \mathrm{m}$ mesh plankton net tows sampled at the Port Aransas south jetty (Texas, USA) during an incoming tide. Tintinnids were picked individually with a micropipette and added to $7 \mathrm{ml}$ micro-wells containing microwave sterilised $0.2 \mu \mathrm{m}$ filtered 30 to $32 \mathrm{ppt}$ seawater (Keller et al. 1988) with $F / 2$ nutrients added. A mixture of the microalgae Heterocapsa rotundata and Isochrysis galbana were added to each micro-well as prey for the isolated ciliates. After a couple of weeks, a few tintinnids were transferred to $50 \mathrm{ml}$ polystyrene tissue culture flasks and the cells were maintained in dim light at $21^{\circ} \mathrm{C}$ feeding on a diet of $I$. galbana until they were needed in experiments. The light was supplied from light fluorescent tubes in a 12:12 h light:dark cycle. The light intensity was kept low $\left(25 \mu \mathrm{mol}\right.$ photons $\left.\mathrm{m}^{-2} \mathrm{~s}^{-1}\right)$ in order to avoid excessive growth of I. galbana in containers with $A$. quadrilineata. No attempts were made to make either ciliate or prey cultures free of bacteria.

Description of organisms used. Amphorides quadrilineata measures ca $75 \times 22 \mu \mathrm{m}$, with a cell volume of $2 \times 10^{4} \mu^{3} \pm \mathrm{SD}=0.66 \times 10^{4}(\mathrm{~N}=30)$ measured on cells fixed in $5 \%$ acid Lugol's. The tintinnid cell is housed in an amphora-shaped lorica with length $\times$ width dimensions of $131.83 \times 29 \mu \mathrm{m}$. The diameter of the anterior opening of the lorica is $41 \mu \mathrm{m}$. Prey cell sizes were estimated from linear dimensions measured in an inverted microscope at a magnification of $1000 \times(\mathrm{N}=30)$, cells fixed in 5\% acid Lugol's) and converted into volumes using appropriate volumetric formula. The volume of Isochrysis galbana was $65 \mathrm{SD} \pm 12$ and $50 \mathrm{SD} \pm 14 \mu \mathrm{m}^{3}$ for Aureoumbra lagunensis. This volume was used throughout all calculations in the present paper.

Aureoumbra lagunensis used as prey was grown and aged for $>1$ mo in order to build up EPS (Villareal et al. 1998), thus resembling A. lagunensis during natural Laguna Madre bloom conditions. The alga was grown in aerated Fernbach flasks in microwave sterilised seawater. Because it uses ammonium as a nitrogen source, ammonium was substituted for nitrate in F/2 nutrients added to the media (DeYoe \& Suttle 1994). Isochrysis galbana used for prey were grown in $250 \mathrm{ml}$ Erlenmeyer flasks using regular $\mathrm{F} / 2$ nutrients added to the medium. Only cells from exponentially growing culture were used in the experiments. Both prey species were cultivated at an irradiance of ca 30 to $50 \mu \mathrm{m} \mathrm{mol}$ photons $\mathrm{m}^{-2} \mathrm{~s}^{-1}$ under the same day:night and temperature regime as with Amphorides quadrilineata.

Mortality. The mortality of Amphorides quadrilineata due to starvation and sudden exposure to monospecific cultures of Aureoumbra lagunensis was compared. Ciliate cells were harvested from a single culture of $A$. quadrilineata growing exponentially on Isochrysis galbana as prey. A. quadrilineata cells were added either to a triplicate series with sterilised seawater with F/2 nutrients without food or to a triplicate series containing $A$. lagunensis added in excess (corresponding to: $5 \times 10^{4}$ cells $\mathrm{ml}^{-1} / 0.34 \mu \mathrm{g} \mathrm{C} \mathrm{l}^{-1} / 2.5 \mathrm{ppm}$ ). Physical conditions regarding light, salinity, plankton wheel set-up and temperature were as stated below in the 'Ciliate growth and grazing' section. A. quadrilineata cell counts were carried out on samples collected at intervals of ca $24 \mathrm{~h}$.

Ciliate growth and grazing. The following protocols apply for all growth and grazing experiments: grazing experiments were carried out in a climate room at a constant temperature of $21 \pm 1^{\circ} \mathrm{C}$. All experiments were run in triplicate in $250 \mathrm{ml}$ polycarbonate flasks. Triplicate controls without predators were run in parallel. The flasks were mounted inside a transparent polystyrene tube (length: $30 \mathrm{~cm}$, diameter: $15 \mathrm{~cm}$ ). The tubes with the bottles inside were rotated on a bottle roller board ( 0.5 to $1 \mathrm{rpm}$ ). Samples were fixed in acid Lugol's solution (final concentration of $4 \%$ ) and counted using an inverted microscope on the same or the following day as samples were taken. A minimum of 400 prey cells were counted in a Sedgwick-Rafter chamber. Ciliates were allowed to settle out and counted in $7 \mathrm{ml}$ micro-wells; 200, and if possible up to 400 , tintinnids were counted in each treatment.

Ciliates in the grazing experiments were allowed to acclimate to the desired prey concentration approx. 
$1 \mathrm{~d}$ before the initial sampling was done. The time interval between sampling was $24 \mathrm{~h}$, equivalent to 1 day:night cycle, thus excluding potential diurnal variations in measured grazing and growth rates. Average prey concentration was calculated as the geometric mean between starting and ending concentrations of prey cells. Prey cell concentration and ingestion rates were converted into either biovolume or carbon using the size:carbon relationship given in Montagnes et al (1994).

The growth rates of both predators and prey were calculated assuming constant logistic growth $\left(N=N_{0} \mathrm{e}^{(t \mu)}\right)$ while feeding with a constant ingestion rate $(I)$. The ingestion rates of tintinnids were estimated as the decrease in prey cells in grazing flasks compared to controls. The model used to estimate the grazing rate was the iterative model used by, e.g., Jakobsen \& Hansen (1997):

$$
\begin{aligned}
& \frac{\mathrm{d} x}{\mathrm{~d} t}=\mu_{x} x-I y \\
& \frac{\mathrm{d} y}{\mathrm{~d} t}=\mu_{y} y
\end{aligned}
$$

The iterative model assumes that the growth rates $(\mu)$ of predator $(y)$ and prey $(x)$ are constant and exponential, with rate constants $\mu_{y}$ and $\mu_{x}$ respectively. The prey mortality induced by predators, $I \times y$, is calculated iteratively using a computer with time steps of $0.01 \mathrm{~h}$. In order to measure predator growth and ingestion rates as closely as possible to balanced growth we only used data from experiments where prey concentrations changed no more than $\pm 30 \%$ of initial prey concentration.

Two series of grazing experiments were run. The first series of experiments was done to establish a 'standard' functional and numerical response for tintinnids with Isochrysis galbana as prey. In the second experimental series, tintinnids were fed a mixed diet of Aureoumbra lagunensis and I. galbana at ratios from high to low in biovolumes corresponding to the biovolume of $I$. galbana sustaining maximum growth. In order to assure that ingestion and growth were saturated throughout the mixed diet experiments, a prey bio-volume ranging from 0.9 to $3.4 \mathrm{ppm}$ was used (mean $1.6 \pm 0.96 \mathrm{SD}$ ). A prey biovolume of $1.6 \mathrm{ppm}$ of A. lagunensis corresponds to $0.22 \mu \mathrm{g} \mathrm{C} \mathrm{ml}^{-1}$ (estimated from Villareal et al. 1998), while the corresponding biovolume of $I$. galbana is equivalent to $0.168 \mu \mathrm{g} \mathrm{C}$ $\mathrm{ml}^{-1}$ based on the size:carbon relationship given in Montagnes et al. (1994). The pH was occasionally measured in the grazing experiments with an Orion portable 200 series $\mathrm{pH}$ meter to ensure that $\mathrm{pH}$ never changed outside the level found in the field (approx. 8.1 to 8.2$)$.
Behaviour experiment. Four replicates of $150 \mathrm{Am}$ phorides quadrilineata were pipetted and transferred to 4 separate $4 \mathrm{ml}$ multidish micro-well plates. Isochrysis galbana was added to each well, making a final prey concentration of $2 \mathrm{ppm}$. The ciliate cells were allowed to feed and acclimate in the climate room for $12 \mathrm{~h}$. After $12 \mathrm{~h}$ the ciliates in each well were videotaped in order to estimate the behavioural parameters of wellfed A. quadrilineata in an undisturbed environment (control). The cells were then transferred by micropipetting to a new set of 4 micro-wells containing F/2 enriched seawater with a total of 150 A. quadrilineata cells in each well. To each well Aureoumbra lagunensis cells were added as prey, making a final concentration of $2 \mathrm{ppm}$. After $10 \mathrm{~min}$ of acclimation, the first video recording of swimming cells was made. Subsequently, the cells were taped after 60 min and again $20 \mathrm{~h}$ after addition of $A$. lagunensis. The behavioural pattern of $A$. quadrilineata was videotaped in microwells covered with a microscope cover glass slide using an Olympus dissection microscope with darkfield illumination. The dissection microscope was fitted with a monochrome video camera connected to a Panasonic AG-1960 SVHS video tape recorder. The videotape was digitised using Motion Analysis VP-110 as described by Buskey \& Stoecker (1988).

\section{RESULTS}

\section{Response of Amphorides quadrilineata to Aureoumbra lagunensis}

Amphorides quadrilineata underwent approx. 1 residual cell division after cells were transferred to a well without food (Fig. 1). After $40 \mathrm{~h}$ the population growth ceased and subsequently $A$. quadrilineata began to die after approx. $75 \mathrm{~h}$ with a mortality rate $\left(\mu \mathrm{d}^{-1}\right)$ of $-9.9 \times 10^{-2}$. When A. quadrilineata was added to Aureoumbra lagunensis, no residual cell division was observed and the number of $A$. quadrilineata remained almost constant for the first $40 \mathrm{~h}$, after which the cells died at a rate $\left(\mu \mathrm{d}^{-1}\right)$ of $-9.5 \times 10^{-2}$. The mortality rates of each treatment were compared, but no significant differences were found $(t=0.0807, \mathrm{p}<0.005)$.

\section{Functional and numerical responses}

The growth $\left(\mu, \mathrm{d}^{-1}\right)$ of Amphorides quadrilineata (Fig. 2) exhibited a steep increase when Isochrysis galbana were offered as prey in concentrations above $0.225 \mathrm{ppm}\left(1 \mathrm{ppm}=1.5 \times 10^{4} \mathrm{I}\right.$. galbana $\left.\mathrm{ml}^{-1}\right)$ and reached maximum growth $\left(0.38 \mathrm{~d}^{-1}\right)$ at around $1 \mathrm{ppm}$ I. galbana $\mathrm{ml}^{-1}$. The predator:prey ratio in terms of cell 


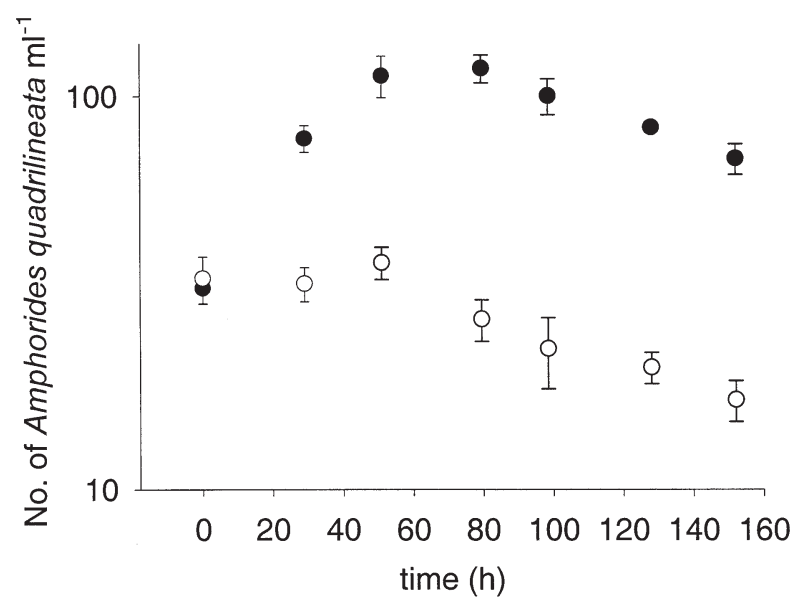

Fig. 1. Number of Amphorides quadrilineata (ciliates $\mathrm{ml}^{-1}$ ) during food depletion (•) and during long-term exposure to a diet consisting solely of Aureoumbra lagunensis (O). Error bars $= \pm \mathrm{SD}$

diameter was ca 7. Growth rates were fitted to a second order curve to provide a general description of the numerical response for suspension-feeding heterotrophic protozoans (Fenchel 1987). Using Sigma Plot ${ }^{\circledR}$ we were able to iteratively fit our experimental data to the following model:

$$
\mu=\frac{\mu_{\max }(X-Z)}{k / 2+(X-Z)}
$$

where $X$ is the actual prey cell concentration, $k / 2$ is the food concentration that sustains $50 \%$ of maximum

$$
\mu \mathrm{gC} \mathrm{ml} l^{-1}
$$

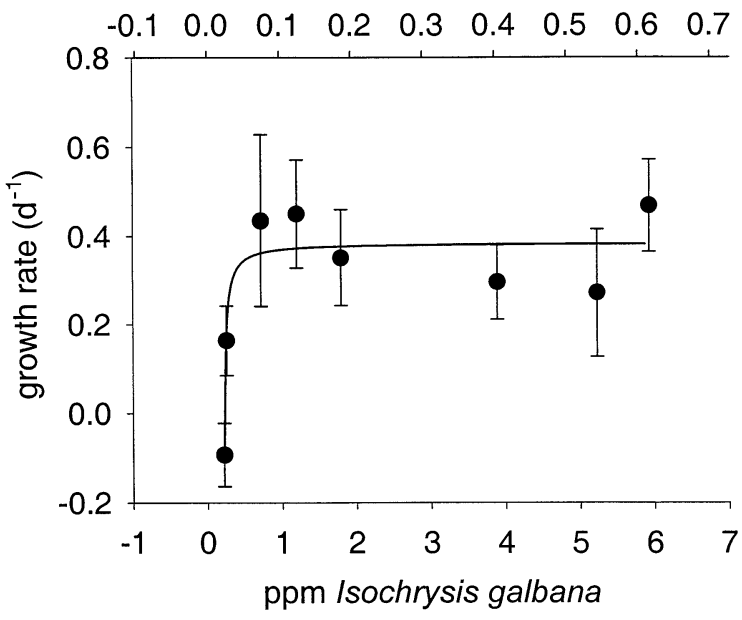

Fig. 2. Amphorides quadrilineata growth rate $\left(\mu, \mathrm{d}^{-1}\right)$ feeding on Isochrysis galbana. Prey concentrations were calculated as geometric mean between start and end prey concentrations. Error bars $= \pm \mathrm{SD}$

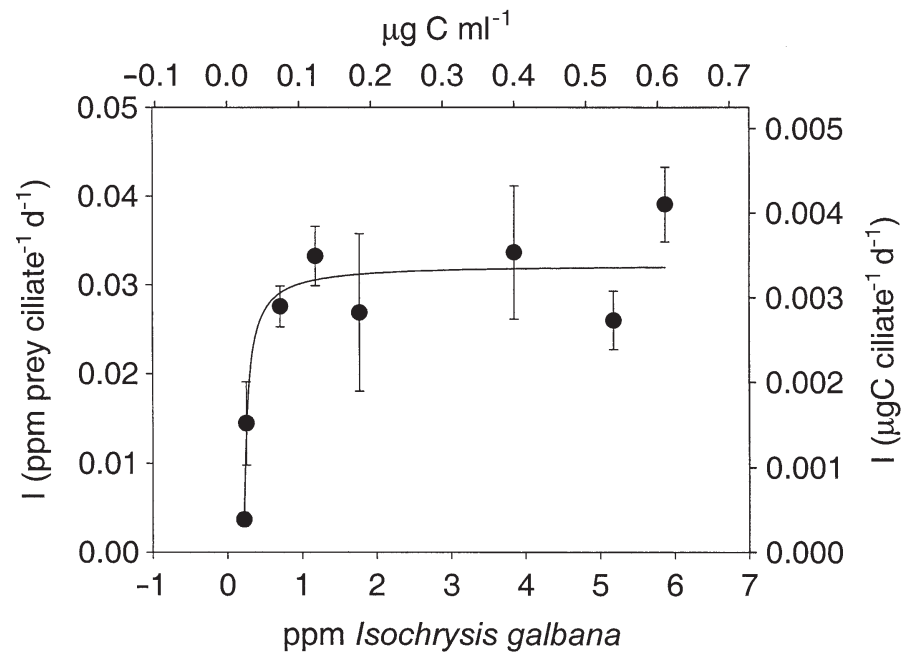

Fig. 3. Amphorides quadrilineata ingestion rate $(I$, prey cili$a^{-1} \mathrm{~d}^{-1}$ ) feeding on Isochrysis galbana. Prey concentrations were calculated as geometric mean between start and end prey concentrations. Error bars $= \pm \mathrm{SD}$

growth, $\mu_{\max }$ is the maximum growth rate and $Z$ is the threshold for growth prey concentration $\mu$, where $\mu=0$. The result of the fit yielded the following characteristics of A. quadrilineata preying on I. galbana:

$$
\mu\left(\mathrm{d}^{-1}\right)=\frac{0.38(X-0.225)}{0.256+(X-0.225)}
$$

The ingestion rate $(I)$ (Fig. 3) increased until a constant maximum level was reached. It can be argued that his type of feeding response follows a Holling type II response for predation (Fenchel 1980) which can be

$\mu \mathrm{g} \mathrm{C} \mathrm{ml}{ }^{-1}$

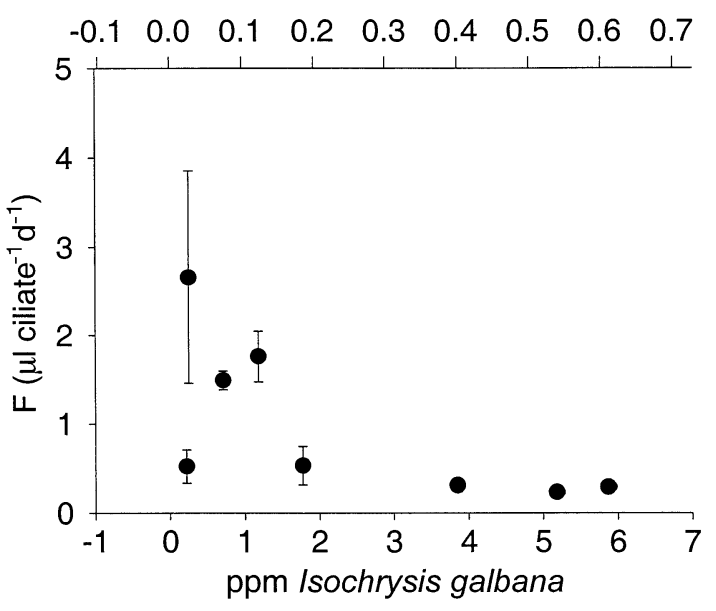

Fig. 4. Amphorides quadrilineata clearance rate $\left(F, \mu\right.$ liliate ${ }^{-1}$ $\mathrm{d}^{-1}$ ) feeding on Isochrysis galbana. Prey concentrations were calculated as geometric mean between start and end prey concentrations. Error bars $= \pm \mathrm{SD}$ 
described by the second order math used to describe growth $(\mu)$ and was similarly determined using Sigma Plot except that $I$ substitutes for $\mu$

$$
I\left(\mathrm{ppm} \mathrm{d}^{-1}\right)=\frac{0.032(X-0.211)}{0.265+(X-0.211)}
$$

When a regression of specific growth against specific ingestion was performed (data not shown), the regression gave a gross growth efficiency (GGE) of $30.2 \%$ $\mathrm{R}^{2}=0.92$. However it must be kept in mind that resources spent forming the lorica are not included in this estimate of the yield. The threshold for growth corresponds with a daily threshold consumption of 140 Isochrysis galbana $\mathrm{d}^{-1}$.

Clearance (Fig. 4) decreased with increasing Isochrysis galbana concentration from a maximum value of $2.7 \mu \mathrm{d} \mathrm{d}^{-1}$ to a minimum of approx. $0.5 \mu \mathrm{d}^{-1}$ per Amphorides quadrilineata. Specific clearance in terms of body volumes ranged from $0.25 \times 10^{5}$ to $1.4 \times 10^{5} \mathrm{~d}^{-1}$.

\section{Mixed diet experiment}

When Amphorides quadrilineata was feeding on Isochrysis galbana and Aureoumbra lagunensis in a mixed diet experiment, population growth (Fig. 5) was largely unaffected when $A$. lagunensis made up less than $40 \%$ of the diet. Transient growth responses were found when the amount of $A$. lagunensis varied between 40 and $60 \%$ of the diet. When A. lagunensis consisted of more than $60 \%$ of the diet, the population growth rate became negative (Fig. 5). The corresponding ingestion rate (Fig. 6) measured was almost constant at approx. $0.026 \mathrm{ppm} \mathrm{d}^{-1}$ as long as growth of $A$. quadrilineata was positive. However when the amount

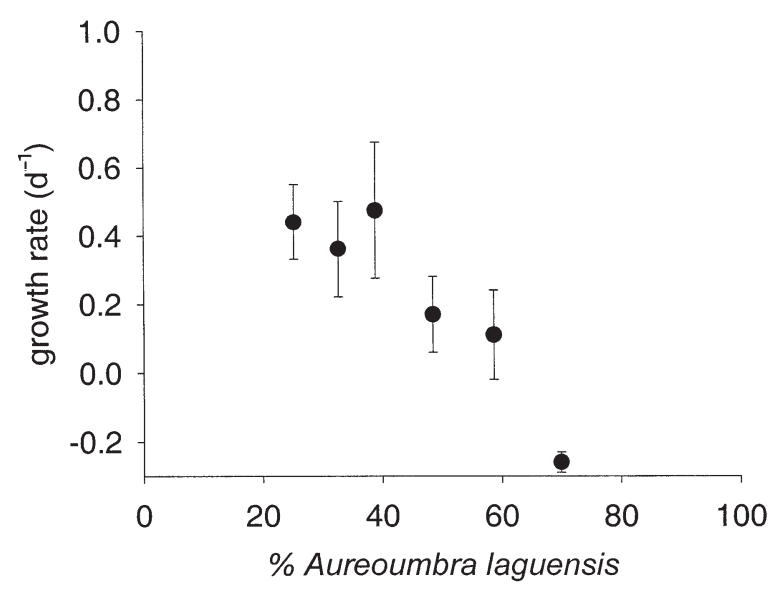

Fig. 5. Amphorides quadrilineata growth rate $\left(\mu, \mathrm{d}^{-1}\right)$ in the mixed diet experiment; changes with increasing content of Aureoumbra lagunensis in the diet. Error bars $= \pm \mathrm{SD}$

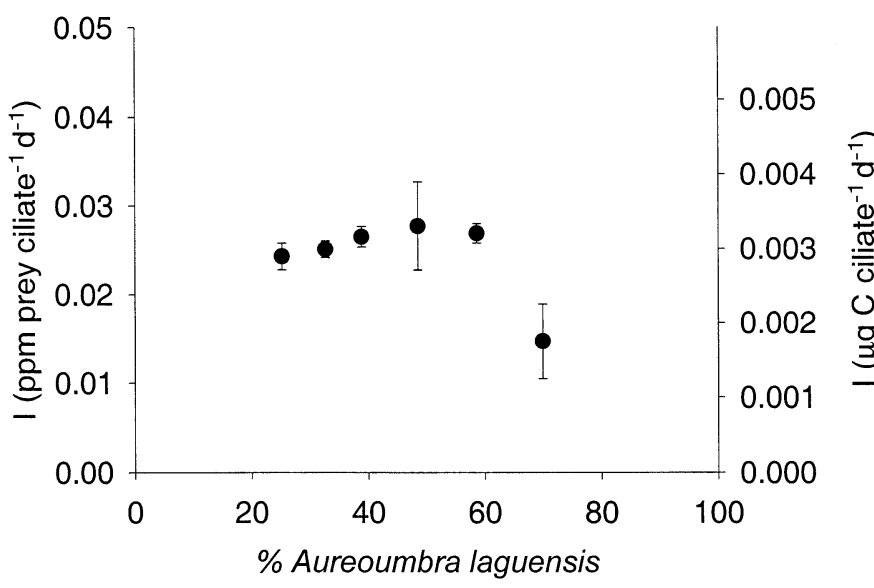

Fig. 6. Amphorides quadrilineata ingestion rate ( $I$, prey ciliate ${ }^{-1}$ $\mathrm{d}^{-1}$ ) in the mixed diet experiment; changes with increasing content of Aureoumbra lagunensis in the diet. Error bars $= \pm \mathrm{SD}$

of $A$. lagunensis in the diet exceeded $60 \%$ and growth became negative, the corresponding ingestion rate decreased.

\section{Behaviour}

The 3 behavioural parameters investigated were swimming speed $\left(\mathrm{mm} \mathrm{s}^{-1}\right)$, turning rate $\left(\mathrm{RCD},{ }^{\circ} \mathrm{s}^{-1}\right)$ and net to gross displacement ratio (NGDR). The speed of Amphorides quadrilineata was unaffected by Aureoumbra lagunensis relative to Isochrysis galbana and no significant differences between treatments were found (Table $1 ; 1$-way ANOVA $\alpha=0.05 ; p=0.695$ ). The differences of NDGR between treatments did not yield any significant difference (Kruskal-Wallis test $\alpha=0.05$; $\mathrm{p}=0.579$ ). The only behavioural parameter that gave a significant difference between treatments was a transient increase in RCD after 60 min (1-way ANOVA $\alpha=0.05 ; \mathrm{p}=0.005$ ).

Table 1. Behavioural parameters for Amphorides quadrilineata estimated when cells were grazing on Isochrysis galbana (control) and after $10 \mathrm{~min}, 60 \mathrm{~min}$ and $20 \mathrm{~h}$ after transfer to addition to wells with Aureoumbra lagunensis.. * Significant differences between treatments and control were found $(\mathrm{SD}=$ standard deviation). RCD: turning rate; NGDR: net to gross displacement ratio

\begin{tabular}{|lccc|}
\hline Treatment & $\begin{array}{c}\text { Swimming speed } \\
\pm \mathrm{SD}\left(\mathrm{cm} \mathrm{s}^{-1}\right)\end{array}$ & $\begin{array}{c}\mathrm{RCD} \pm \mathrm{SD} \\
\left({ }^{\circ} \mathrm{s}^{-1}\right)\end{array}$ & NGDR $\pm \mathrm{SD}$ \\
\hline Control & $0.0242 \pm 0.04$ & $110 \pm 14$ & $0.851 \pm 0.02$ \\
$10 \mathrm{~min}$ & $0.0247 \pm 0.05$ & $125 \pm 9$ & $0.843 \pm 0.01$ \\
$60 \mathrm{~min}$ & $0.0213 \pm 0.05$ & $163^{*} \pm 16$ & $0.867 \pm 0.01$ \\
$20 \mathrm{~h}$ & $0.0227 \pm 0.04$ & $146 \pm 26$ & $0.872 \pm 0.05$ \\
\hline
\end{tabular}




\section{DISCUSSION}

The ciliate Amphorides quadrilineata grew well on the alga Isochrysis galbana with a growth rate close to that expected from scaling relationships between size and growth of ciliates (Hansen et al. 1997). Also, since A. quadrilineata was isolated from an area unaffected by Aureoumbra lagunensis close to Laguna Madre, we believe that tintinnid ciliates like $A$. quadrilineata are among the potential pioneer species in controlling growth of A. lagunensis since it can feed on prey sizes similar to A. lagunensis. Before the onset of the $A$. lagunensis bloom, oligotrich loricate ciliates were seasonally among the most abundant protozoan grazers near the Laguna Madre (Buskey 1993). However, the blooming of the brown tide alga A. lagunensis negatively affected the growth of heterotrophic microzooplankton (Buskey \& Hyatt 1995), thus decreasing the abundance of oligotrich ciliates such as tintinnids in Laguna Madre (Buskey \& Stockwell 1993). The results of this study correspond well with these observations.

When Amphorides quadrilineata grown on Isochrysis galbana was exposed to Aureoumbra lagunensis, the effect was immediate and on a similar time scale to the effect of food depletion (Fig. 1). Although A. quadrilineata was affected by $A$. lagunensis, the effecting component of $A$. lagunensis did not kill A. quadrilineata, but instead arrested residual cell division. The differences in the pattern of mortality for A. quadrilineata due to starvation and for $A$. quadrilineata exposed to A. lagunensis suggest that the effects of A. lagunensis arise from more than 1 factor. Our study suggests that either cell division or some biochemical processes associated with growth of $A$. quadrilineata is blocked immediately upon exposure to A. lagunensis. After a period corresponding to the length of the residual growth of starving $A$. quadrilineata, starvation or ageing of cells exposed to A. lagunensis may come into effect since $A$. quadrilineata populations exposed to $A$. lagunensis declined at the same rate as food-depleted cells. Although the growth-effecting agent of A. lagunensis could not be identified per se, it must arise from an internal cell component, since the inhibition of ciliate population growth was diluted out with the alternative prey, I. galbana, regardless of the A. lagunensis concentrations used in the mixed diet experiment. When $A$. quadrilineata cells were offered a mixed diet of A. lagunensis and I. galbana as prey, the growth of A. quadrilineata decreased with the proportion of added A. lagunensis when it made up more than $40 \%$ of the diet (Fig. 5). However, ingestion rates were constant until the growth of $A$. quadrilineata became negative at $A$. lagunensis concentrations exceeding $60 \%$. Liu \& Buskey (2000b) found that the amount of EPS in $A$. lagunensis affected feeding rates of ciliates and sug- gested that EPS may block the feeding organelles of ciliates. Using video techniques Kamiyama \& Arima (1997) found that blocking of the feeding organelles in the tintinnid Favella taraikaensis prevented the ciliate from feeding as long as Heterocapsa circularisquama adhered to the feeding organelles. However blocking of the cytostome in F. taraikaensis was followed by a subsequent rejection of the prey dinoflagellate. In contrast A. quadrilineata in our study ingested A. lagunensis cells at the same rate as the good food, I. galbana, in the mixed diet experiment thus excluding prey-handling problems for A. quadrilineata feeding on A. lagunensis. However, the prey concentrations that we used in the mixture experiment were $>1 \mathrm{ppm}$ prey, and it may very well be that ingestion is negatively affected at sub-maximum prey concentrations due to effects on the feeding apparatus of A. quadrilineata.

Amphorides quadrilineata ingested Aureoumbra lagunensis until its growth ceased, making it unlikely that $A$. lagunensis had cell surface properties alerting the ciliate of its potential unsuitability as prey. The presence of $A$. lagunensis does not induce any selection against the good food, since there is a linear relationship between ingestion of $A$. lagunensis and the relative concentration of $A$. lagunensis available (Fig. 7), nor does $A$. lagunensis induce any avoidance behaviour in A. quadrilineata. In fact, the behaviour experiment suggests a weak positive response to A. lagunensis since the RCD transiently increases after $60 \mathrm{~min}$. A transient increased turning rate of tintinnids has previously been interpreted as a swimming response performed in order to exploit food patches (Buskey \& Stoecker 1988, Fenchel \& Jonsson 1988). Lui \& Buskey

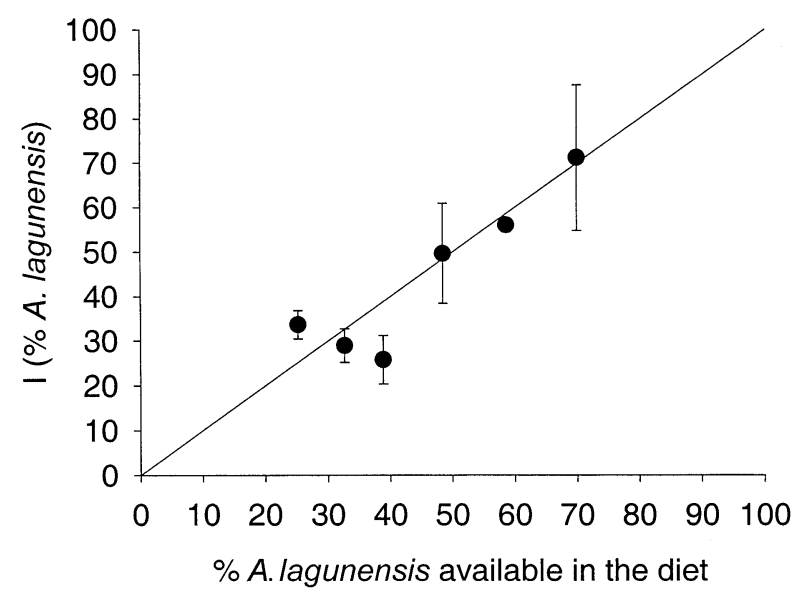

Fig. 7. Aureoumbra lagunensis ingestion $(I)$ in percent of total biovolume ingested versus percent A. lagunensis available in the mixed diet experiment. Data are normalised by prey volume. Error bars $= \pm \mathrm{SD}$ 


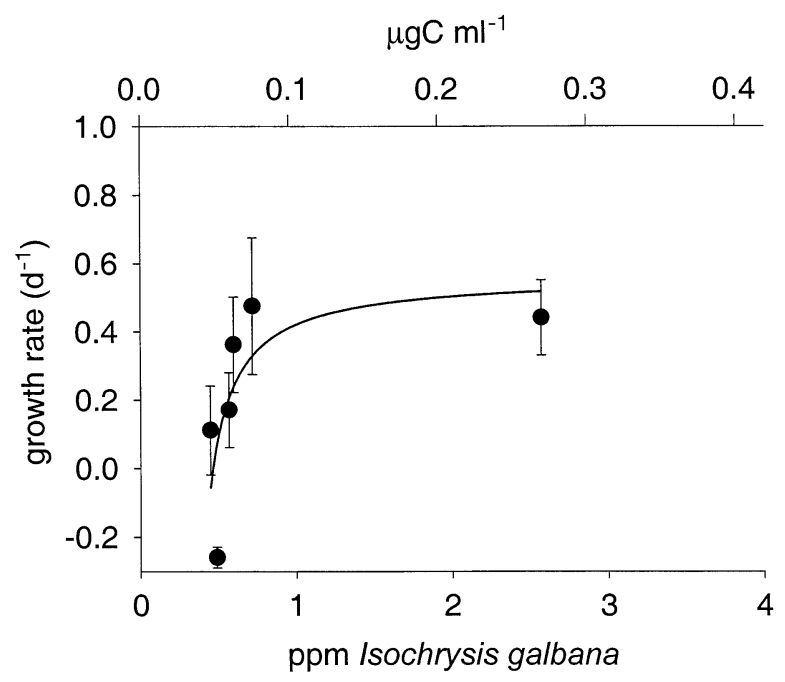

Fig. 8. Amphorides quadrilineata growth rate $\left(\mu, \mathrm{d}^{-1}\right)$ versus Isochrysis galbana concentration in the mixed diet experiment. Prey concentrations were calculated as geometric mean between start and end prey concentrations. Error bars $= \pm \mathrm{SD}$

(2000b) also observed an increase in RCD in the benthic ciliate Aspidisca sp. when they offered it a diet of A. lagunensis with high EPS compared to low EPS cells. They speculated that their finding was a result of a negative interference of EPS with the swimming and feeding organelles of Aspidisca sp.

Villareal et al. (1998) found that the proportion of carbon increased relative to nitrogen and phosphorus in Aureoumbra lagunensis with the age of the cells, due to a build-up of EPS. The increased C:N may turn A. lagunensis into a poor food source and reduce growth of protists feeding on A. lagunensis. Comparing the $\mathrm{C}$ and $\mathrm{N}$ intake of Amphorides quadrilineata feeding on mono-specific Isochrysis galbana and a mixed diet of A. lagunensis and I. galbana suggests that the nitrogen supply in the mixed diet is sufficient to maintain positive growth of $A$. quadrilineata (Table 2). Even when growth of A. quadrilineata $=0$ in the mixed diet experiment, the $\mathrm{C}$ and $\mathrm{N}$ intake are of the same magnitude as the corresponding food intake when feeding on I. galbana alone (Table 2). However it cannot be ruled out that EPS or the high C:N content make A. lagunensis indigestible, since the growth of A. quadrilineata in the mixed diet largely followed the concentration of I. galbana (Fig. 8) and the mortality of A. quadrilineata after ca $60 \mathrm{~h}$ of exposure to A. lagunensis was similar to the mortality rate of starving $A$. quadrilineata cells, indicating that starvation played a role in the post exposure effect of A. lagunensis. Also, nutrients other than $\mathrm{C}$ and $\mathrm{N}$ may be limiting for predators feeding on $A$. lagunensis but data on this issue are presently limited.

\section{ECOLOGICAL IMPLICATIONS}

There is a well-documented historical record of the heterotrophic protist abundance in the Laguna Madre before the onset of the Aureoumbra lagunensis bloom, and from these records it is evident that it was not the A. lagunensis per se which originally disrupted the microzooplankton food web (Buskey et al. 1997,1998). The heterotrophic protist biomass had already been drastically reduced before the onset of the bloom. The reduction of grazers has been suggested to be due to hypersaline conditions (>60 ppt) caused by a severe drought (Buskey et al. 1997). The absence of grazers may subsequently have allowed the bloom to develop undisturbed, since A. lagunensis seems better fit to cope with hypersalinity than other algae (Buskey et al. 1998, Lui \& Buskey 2000a). Our findings showed that growth of Amphorides quadrilineata is reduced by $A$. lagunensis, but ingestion rate, in terms of volume or carbon, is constant in the mixed diet experiment. We believe that lack of prey selection for $A$. quadrilineata feeding on A. lagunensis (Fig. 7) may explain the general absence of tintinnid ciliates, and possibly other oligotrich ciliate species, in waters dominated by highdensity blooms of the brown tide alga A. lagunensis. In an environment with physical conditions such as those found in Laguna Madre before the bloom of A. lagu-

Table 2. Carbon and nitrogen uptake by Amphorides quadrilineata feeding on mono-specific Isochryis galbana or when feeding on a mixed diet ( $60 \%$ A. lagunensis and $40 \%$ I. galbana)

\begin{tabular}{|c|c|c|c|c|c|}
\hline \multicolumn{4}{|c|}{ Feeding on I. galbana } & \multirow{2}{*}{\multicolumn{2}{|c|}{$\begin{array}{c}\text { Feeding on mixture } \\
\text { Threshold ingestion for growth of } \mu=0 \\
\left(\operatorname{pg~d}^{-1} \text { A. quadrilineata }{ }^{-1}\right)\end{array}$}} \\
\hline \multicolumn{2}{|c|}{$\begin{array}{l}\text { Maximum ingestion for growth } \\
\left(\mathrm{pg} \mathrm{d}^{-1} \text { A. quadrilineata }{ }^{-1}\right)\end{array}$} & \multicolumn{2}{|c|}{$\begin{array}{l}\text { Threshold ingestion for growth } \\
\quad\left(\mathrm{pg} \mathrm{d}^{-1} \text { A. quadrilineata }{ }^{-1}\right)\end{array}$} & & \\
\hline Carbon $^{a}$ & Nitrogen $^{\mathrm{a}}$ & Carbon $^{a}$ & Nitrogen $^{a}$ & Carbon $^{a, b}$ & Nitrogen $^{\mathrm{a}, \mathrm{b}}$ \\
\hline 3275 & 590 & 955 & 172 & 3307 & 559 \\
\hline
\end{tabular}


nensis, or in adjacent Corpus Christi Bay, blooms will rarely develop due to protist grazers feeding on a diverse assemblage of phytoplankton cells. However when the A. lagunensis bloom is established, heterotrophic grazers like tintinnids are unable to graze it down since the ratio between A. lagunensis and other nanoflagellates will be periodically unfavourable for ciliates such as the studied $A$. quadrilineata. In addition, in semi-enclosed systems like Laguna Madre, phytoplankton species may have difficulties in inoculating to establish viable populations. Admittedly, protist other than those that typically occurred before the bloom, such as the species studied by Lui \& Buskey (2000b), may benefit from the lack of planktonic protist species and thus take their place in the planktonic food web feeding on A. lagunensis. Some protist species are found to be able to grow on mono-specific blooms of $A$. lagunensis (Buskey \& Hyatt 1995, Lui \& Buskey 2000b) although these heterotrophic protists are apparently not able to efficiently control and graze down the $A$. lagunensis bloom. The reasons for this may be complex, but the elevated salinity may play a substantial role since the hypersaline conditions may depress growth of protist predators to a level that is too low to outbalance predation from metazoans such as copepods (Buskey et al. 1998). In addition, the present or absence of other phytoplankton species may play an important role as an alternative prey that can dilute $A$. lagunensis and make them edible to protists. Re-inoculation of oligotrich microzooplankton grazers and subsequent top-down control of the A. lagunensis bloom will, according to this study, only occur when alternative prey nanoflagellates are available at at least approximately equal ratios of $A$. lagunensis.

Acknowledgements. This work is a part of a $\mathrm{PhD}$ study by H.H.J. supported by a grant to H.H.J. from the Danish Research Academy; the Christian and Ottilia Brorsons memorial fund covered travel expenses for H.H.J. from Denmark to Texas, USA. Research at the University of Texas Marine Science Institute was supported by NSF grant OCE-9529750 to E.J.B. Thanks are given to Per Juel Hansen and 3 anonymous reviewers for their comments, which improved the manuscript.

\section{LITERATURE CITED}

Buskey EJ (1993) Annual pattern of micro- and mesozooplankton abundance and biomass in a subtropical estuary. J Plankton Res 15:907-924

Buskey EJ, Hyatt C (1995) Effects on the Texas (USA) 'brown tide' alga on planktonic grazers. Mar Ecol Prog Ser 126: 285-292

Editorial responsibility: David Caron,

Los Angeles, California, USA
Buskey EJ, Stockwell DA (1993) Effects of a persistent 'brown tide' on zooplankton populations in the Laguna Madre of south Texas. In: Smayda TJ, Shimuizu Y (eds) Toxic phytoplankton blooms in the sea. Proc 5th Int Conf on Toxic Marine Phytoplankton. Elsevier Science Publishers, Amsterdam, p 659-666

Buskey EJ, Stoecker DK (1988) Locomotory patterns of the planktonic ciliat Favella sp.: adaptations for remaining within food patches. Bull Mar Sci 43:783-796

Buskey EJ, Montagna PA, Amos F, Whitledge E (1997) Disruption of grazer population as a contribution factor to the initiation of the Texas brown tide algal bloom. Limnol Oceanogr 42:1215-1222

Buskey EJ, Wysor B, Hyatt C (1998) The role of hypersalinity in the persistence of the Texas 'brown tide' bloom in the Laguna Madre. J Plankton Res 20:1553-1565

DeYoe HR, Suttle CA (1994) The inability of the Texas 'brown tide' alga to use nitrate and the role of nitrogen in the initiation of a persistent bloom of this organism. J Phycol 30: $800-806$

Fenchel T (1980) Suspension feeding in ciliated protozoa: functional response and particle size selection. Microb Ecol 6: $1-11$

Fenchel T (1987) Ecology of protozoa. Springer Verlag, Berlin

Fenchel T, Jonsson PR (1988) The functional biology of Strombidium sulcatum, a marine oligotrich ciliate (Ciliophora, Oligotrichina). Mar Ecol Prog Ser 48:1-15

Hansen PJ, Bjørnsen PK, Hansen B (1997) Zooplankton grazing and growth: scaling within the $2-2000 \mu \mathrm{m}$ body range. Limnol Oceanogr 42:687-704

Jakobsen HH, Hansen PJ (1997) Prey size selection, grazing and growth response of the small heterotrophic dinoflagellate Gymnodinium sp. and the ciliate Balanion comatum-a comparative study. Mar Ecol Prog Ser 158:75-86

Kamiyama T, Arima S (1997) Lethal effect of the dinoflagellate Heterocapsa circularisquama upon the tintinnid ciliate Favella taraikaensis. Mar Ecol Prog Ser 160:27-33

Keller MD, Bellows WK, Guillard RRL (1988) Microwave treatment for sterilization of phytoplankton culture media. J Exp Mar Biol Ecol 117:279-283

Liu H, Buskey EJ (2000a) Hypersaline enhances extracellular polymeric substance (EPS) production of Texas brown tide algae, Aureoumbra lagunensis. J Phycol 36:71-77

Liu H, Buskey EJ (2000b) The exopolymer secretion (ESP) layer surrounding Aureoumbra lagunensis effects growth, grazing and behavior of protozoa. Limnol Oceanogr 45: $1187-1191$

Montagnes DJS, Berges JA, Harrison PJ, Taylor FJR (1994) Estimating carbon, nitrogen, protein, and chlorophyll a from volume in marine phytoplankton. Limnol Oceanogr 39:1044-1060

Suzuki T, Taniguchi A (1998) Standing corps and vertical distribution of four groups of marine planktonic ciliates in relation to phytoplankton chlorophyll a. Mar Biol 132: $375-382$

Villareal TA, Mansfield A, Buskey EJ (1998) Growth and chemical composition of the Texas brown tide-forming pelageophyte Aureoumbra lagunensis. In: Reguera B, Blanco J, Fernandes L, Wyatt T (eds) Harmful algae. VIII international conference. Xuenta de Galicia and Intergovernmental Oceanographic Commision of UNESCO, Vigo, p 359-362

Submitted: August 10, 2000; Accepted: December 14, 2000 Proofs received from author(s): January 31, 2001 